\title{
Analisis Gerakan Literasi Sekolah Pada Pembelajaran Tematik
}

\author{
El Frisa Yunita Anindya ${ }^{1 *}$, Sri Suneki², Veryliana Purnamasari ${ }^{3}$
}

1,2,3 Pendidikan Guru Sekolah Dasar, Fakultas Ilmu Pendidikan, Universitas PGRI Semarang

\author{
A R T I C L E I N F O \\ Article history: \\ Received 10 February \\ 2019 \\ Received in revised form \\ 09 March 2019 \\ Accepted 15 April 2019 \\ Available online 25 May \\ 2019 \\ Kata Kunci: \\ Gerakan Literasi Sekolah \\ (GLS), pembelajaran \\ tematik \\ Keywords: \\ School Literacy Movement \\ (GLS), thematic learning
}

\begin{abstract}
A B S T R A K
Kemampuan berliterasi siswa berkaitan erat dengan tuntutan keterampilan membaca yang berujung pada kemampuan memahami informasi secara analitis dan kritis serta diperlukannya penguasaan keterampilan yang berupa literasi dasar. Penelitian deskripsi kualitatif menggunakan metode observasi, wawancara, angket, dan dokumentasi. Penelitian mengambil subyek 4 kelas dengan sampel yang diambil dari siswa kelas tinggi beserta guru kelas tinggi SD $\mathrm{N}$ Kandang Panjang 10 Pekalongan diolah dengan secara triangulasi data. Hasil Penelitian menunjukkan bahwa pelaksanaan Gerakan Literasi Sekolak (GLS) diketahui dari hasil pengisi angket oleh seluruh siswa kelas tinggi di SD N Kandang Panjang 10 Pekalongan pada tahap pembiasaan $(55,8 \%)$ pada kategori baik. Kriteria tahapan pembelajaran pada kategori baik $(72,92 \%)$. Sarana dan prasarana yang cukup memadai dengan adaya pojok baca disetiap ruang kelas dengan koleksi buku yang bervariasi, koridor sekolah terdapat poster, serta tersedia mading untuk meletakkan hasil karya tulis siswa.
\end{abstract}

\section{A B S T R A C T}

\begin{abstract}
The ability of student literacy is closely related to the demands of reading skills which lead to the ability to understand information analytically and critically and the need for mastering skills in the form of basic literacy. Research qualitative description using observation, interview, questionnaire, and documentation methods. The study took 4 classes of subjects with samples taken from high-class students along with high-class teachers of SD N Kandang Panjang 10 Pekalongan processed by data triangulation. The results showed that the implementation of the Dissolved Literacy Movement (GLS) was known from the results of questionnaire fillers by all high-class students in SD N Kandang Panjang 10 Pekalongan in the habituation stage (55.8\%) in the good category. The criteria for the learning stage are in the good category (72.92\%). Sufficient facilities and infrastructure with a reading corner in each class room with a varied collection of books, a school corridor with posters, and a magazine to put the students' writing.
\end{abstract}

\section{Pendahuluan}

Kemajuan dari suatu bangsa dapat dilihat dari masyarakatnya. Bagaimana mereka berperilaku dan berpikir yang merupakan cerminan seberapa besar pendidikan melekat dalam kehidupan sehari-hari. Pendidikan merupakan sebuah wadah pembentuk kualitas suatu bangsa. Pasal 1 ayat 1 UU No. 20 tahun 2003 tentang Sistem Pendidikan Nasional menyatakan, "Pendidikan adalah usaha sadar dan berencana untuk mewujudkan suasana belajar dan proses pembelajaran agar siswa secara aktif mengembangkan potensi dirinya untuk memiliki kekuatan spiritual keagamaan, pengendalian diri, kepribadian, kecerdasan, akhlak mulia serta keterampilan yang diperlukan dirinya, masyarakat, bangsa dan negara."

Undang-undang Sistem Pendidikan Nasional pasal 51 ayat 1 menyebutkan bahwa : "pengelolaan satuan pendidikan anak usia dini, pendidikan dasar dan pendidikan menengah dilaksanakan berdasarkan standar pelayanan minimal dengan prinsip manajemen berbasis sekolah". Upaya meningkatkan kualitas pendidikan terus menerus dilakukan, salah satunya yaitu dengan pembaharuan kurikulum. 
Pengembangan pendidikan di Sekolah Dasar (SD) dilandasi tiga aspek utama, yaitu karakteristik pendidikan di SD, karakteristik psikologis, dan karakteristik sosiobudaya siswa. Pendidikan dasar memiliki karakter yang khas yang membedakannya dengan pendidikan menengah. Pendidikan menengah lebih menekankan penguasaan akademik, sementara pendidikan dasarlebih menekankan pendidikan karakter/kepribadian, dan literasi (Kemendikbud, 2016: 4).

Pembelajaran tematik dirancang dalam rangka meningkatkan hasil belajar yang optimal dan maksimal dengan cara mengangkat pengalaman anak didik yang mempunyai jaringan dari berbagai aspek pengatahuan dan kehidupannya. Mengintergarsikan antara satu pengalaman dengan pengalaman lain atau antara satu pengetahuan dengan pengetahuan yang lain bahkan antara pengalaman dengan pengetahuan dan sebaliknya memberikan kebermaknaan dalam pembelajaran dalam arti bahwa pembelajaran itu memberikan memberikan fungsi yang berguna bagi kehidupan siswa (Kadir, 2014 : 7).

Pengembangan pendidikan di Sekolah Dasar (SD) dilandasi tiga aspek utama, yaitu karakteristik pendidikan di SD, karakteristik psikologis, dan karakteristik sosiobudaya siswa. Pendidikan dasar memiliki karakter yang khas yang membedakannya dengan pendidikan menengah. Pendidikan menengah lebih menekankan penguasaan akademik, sementara pendidikan dasar lebih menekankan pendidikan karakter/kepribadian, dan literasi (Kemendikbud, 2016: 4).

Literasi merupakan salah satu cara untuk mengembangkan pendidikan. Pada saat ini, kemampuan berliterasi siswa berkaitan erat dengan tuntutan keterampilan membaca yang berujung pada kemampuan memahami informasi secara analitis dan kritis. Selain itu, diperlukan penguasaan keterampilan yang berupa literasi dasar. Akan tetapi, pembelajaran di sekolah saat ini belum mampu mewujudkan hal tersebut.

Berdasarkan hasil obeservasi di SD N Kandang Panjang 10 Pekalongan dapat diketahui bahwa gerakan literasi sekolah belum berjalan dengan maksimal. Dalam pelaksanaan gerakalan literasi di kelas khususnya dalam untuk membantu proses pembelajaran masih mengalami kendala seperti jumlah buku, terbatasnya waktu untuk melaksanakan gerakan literasi, serta lingkungan dan cuaca.

Berdasarkan hal tersebut, peneliti bermaksud melakukan penelitian mengenai gerakan literasi sekolah pada pembelajaran tematik di SD N Kandang Panjang 10 Pekalongan.

Literasi sekolah dalam konteks gerakan literasi sekolah adalah kemampuan mengakses, memahami dan menggunakan sesuatu secara cerdas melalui berbagai aktivitas, antara lain membaca, melihat, menyimak, menulis, dan atau berbicara (Kemendikbud, 2016: 2).

Membaca berperan penting dalam kehidupan, karena salah satu cara untuk menambah pengetahuan didapat dari membaca. Dengan membaca siswa dapat memperoleh beragam informasi yang dapat menunjang proses belajarnya. Peraturan Menteri Pendidikan dan Kebudayaan Nomor 23 Tahun 2015 tentangPenumbuhan Budi Pekerti, salah satunya mengenai kegiatan membaca buku non pelajaran selama lima belas menit sebelum waktu belajar dimulai. Kegiatan tersebut adalah upaya menumbuhkan kecintaan membaca kepada peserta didik dan pengalaman belajar yang menyenangkan sekaligus merangsang imajinasi.

Kegiatan dalam GLS dilaksanakan sesuai dengan kegiatan pembelajaran pada Kurikulum 2013. Implementasi Kurikulum 2013 di sekolah dasar menggunakan model pembelajaran terpadu. Salah satu model pembelajaran terpadu adalah pembelajaran tematik. Pembelajaran tematik dilaksanakan dengan menggabungkan beberapa mata pelajaran menjadi satu kesatuan dalam sebuah tema pembelajaran.

Menurut Kementerian Pendidikan dan Kebudayaan indikator yang digunakan untuk mengukur kemampuan literasi baca-tulis di sekolah dalam basis kelas adalah sebagai berikut: 1) Jumlah fasilitator literasi baca-tulis untuk kepala sekolah, guru, dan tenaga kependidikan; 2) Intensitas pemanfaatan dan penerapan literasi numerasi dalam kegiatan pembelajaran, baik berbasis masalah, maupun berbasis proyek; 3) Skor PISA, PIRLS, dan INAP mengenai literasi membaca.

Pada tahap pembiasaan literasi khususnya pada kelas tinggi kecakapan literasi meliputi komunikasi dan berprikir kritis. Komunikasi dalam kecakapan literasi pada tahap pembiasaan yaitu mempresentasikan cerita dengan efektif. Berpikir kritis pada tahap pembiasaan yaitu untuk mengetahui jenis tulisan dalam media dan tujuannya.

Dalam fokus dan prinsip kegiatan membaca pada tahap pembiasaan jenjang SD kelas tinggi meliputi menyimak, membaca, fokus kegiatan jenis bacaan serta sarana dan prasarana. Menyimak lebih lama untuk memahami isi dari suatu bacaan. Pada kegiatan membaca difokuskan dalam memahami isi bacaan dengan berbagai strategi (mengenali jenis teks, membuat inferensi, koneksi dengan pengalaman / teks lain, dan lain-lain. Untuk fokus kegiatan dilakukan dengan membacakan buku dengan nyaring dan membaca dalam hati. Jenis bacaan yang digunakan dalam tahap pembiasaan ini terdiri atas buku cerita bergambar, buku bergambar kaya teks, serta buku novel pemula. Untuk menunjang minat baca sarana dan prasarana yang harus terpenuhi antara lain sudut buku kelas, perpustakaan, dan area baca. 
Pada tahap pengembangan, kecakapan literasi pada jenjang SD kelas tinggi terdapat menyimak cerita untuk menumbuhkan empati. Pada tahap membaca terdiri atas tiga kecakapan yaitu membaca cerita dengan fasih, menggunakan konteks kalimat untuk memaknai kata-kata baru, memahami cerita fantasi dan cerita rakyat dalam konteks budaya yang spesifik. Dalam kecakapan berbicara berupa menceritakan ulang isi cerita dengan bahasa sendiri dan mengemukakan pendapat terhadap cerita. Kecakapan menulis dalam tahap pengembangan ini memiliki dua kecakapan diantaranya yaitu menuliskan tanggapan terhadap tokoh/alur cerita dan menulis memodifikasi cerita dalam alur awal, tengah, akhir cerita. Sama halnya dengan menulis, memilah infomasi terdapat dua kecakapan yaitu menidentifikasi elemen fakta dan fiksi dalam cerita serta mengidentifikasi perbedaan dan persamaan karakter tokoh-tokoh cerita.

Kecakapan literasi pada tahap pembelajaran dalam jenjang kemampuan membaca pemula sebagian SD kelas rendah dan tinggi memiliki kelompok kemampuan diantaranya yaitu; 1) kemampuan fonetik yang memiliki dua tingkat kemampuan yaitu mengeja sebagian kombinasi huruf-huruf (konsonan dan vokal) secara mandiri serta mengeja kombinasi huruf-huruf lain dengan bantuan. 2) Pemahaman kosa kata dengan kemampuan memahami hampir sebagian besar kata-kata yang dibaca dengan atau tanpa bantuan. 3) Pemahaman tata bahasa, kemampuan memahami fungsi tanda baca titik, koma, dan tanya. 4) kemampuan menggunakan konteks, yaitu mampu menggunakan ilustrasi untuk memahami bacaan. 5) Kemampuan menginterpretasi dan merespons bacaan dengan dapat menjawab hampir semua pertanyaan terkait bacaan. 6) perilaku membaca, kemampuan mendengar dan menyimak sepanjang waktu ketika membaca dengan panduan/dibacakan.

Pada jenjang pembaca madya kelas tinggi memiliki kelompok kemampuan yaitu; 1) Kemampuan fonetik, diharapkan dapat mengeja semua kombinasi huruf-huruf dengan baik. 2) Pemahaman kosa kata, dengan memahami sebagian besar kata-kata tanpa bantuan. 3) Pemahaman tata bahasa dengan kemampuan memahami hampir semua tanda baca, titik, koma, tanda tanya, tanda seru, tanda kutip serta membaca dengan intonasi yang sesuai dengan tanda baca (titik, koma, tanda tanya dan seru). 4) Kemampuan menggunakan konteks dengan memahami arti kalimat dengan menggunakan pemahaman terhadap kata-kata yang telah diketahui. 5) kemampuan yang menginterpretasi dan merespons bacaan dibagi menjadi tiga kemampuan yaitu kemampuan menjawab semua pertanyaan terkait bacaan, kemampuan menjelaskan ulang informasi umum dan sebagian informasi spesifik terkait bacaan, serta kemampuan melakukan inferensi dan prediksi terkait bacaan. 6) Kelompok kemampuan perilaku membaca digolongkan dalam dua kemampuan yaitu kemampuan menunjukkan minat terhadap bacaan serta memilih buku secara mandiri sesuai dengan minatnya dengan atau tanpa bimbingan.

Kegiatan yang dapat dilakukan di tahap pembelajaran antara lain sebagai berikut. 1) Guru mencari metode pengajaran yang efektif dalam mengembangkan kemampuan literasi peserta didik. Untuk mendukung hal ini, guru dapat melakukan penelitian tindakan kelas. 2) Guru mengembangkan rencana pembelajaran sendiri dengan memanfaatkan berbagai media dan bahan ajar. 3) Guru melaksanakan pembelajaran dengan memaksimalkan pemanfaatan sarana dan prasarana literasi untuk memfasilitasi pembelajaran. 4) Guru menerapkan berbagai strategi membaca (membacakan buku dengan nyaring, membaca terpandu, membaca bersama) untuk meningkatkan pemahaman peserta didik terhadap materi pembelajaran.

Pemanfaatan perpustakaan dan sudut baca sekolah bertujuan untuk meningkatkan kecakapan literasi perpustakaan (library literacy) peserta didik. Kecakapan literasi perpustakaan meliputi: 1) Pengetahuan tentang fungsi perpustakaan sebagai sumber pengetahuan dan koleksi informasi yang bermanfaat dan menghibur. 2) Kemampuan memilih bahan pustaka yang sesuai jenjang dan minat secara mandiri. 3) Pengetahuan tentang bahan pustaka sebagai produk karya penulisan yang diciptakan melalui proses kreatif. 4) Pengetahuan tentang etika meminjam bahan pustaka dan berkegiatan di perpustakaan.

Kegiatan literasi pada tahap pembelajaran meningkatkan kemampuan berbahasa reseptif (membaca dan menyimak) dan aktif (berbicara dan menulis). Kemampuan membaca dan menulis dijenjangkan agar peningkatan kecakapan di empat area berbahasa tersebut (membaca, menyimak, berbicara, dan menulis) dapat dilakukan secara terukur dan berkelanjutan. Jenjang kemampuan membaca dan menulis dibagi dalam tiga tingkatan: awal, pemula, dan madya, yang merentang dari SD kelas rendah ke kelas tinggi (Kemendikbud, 2016: 57).

Pembelajaran tematik terpadu menggunakan tema sebagai pemersatu kegiatan pembelajaran yang memadukan beberapa mata pelajaran sekaligus dalam satu kali tatap muka, untuk memberikan pengalaman yang bermakna bagi peserta didik (Kemendikbud, 2016: 12).

Dalam kurikulum 2013 menggunakan metode pembelajaran tematik terpadu. Pembelajaran tematik menawarkan model-model pembelajaran yang menjadikan aktivitas pembelajaran itu relevan dan penuh makna bagi siswa, baik aktivitas formal maupun informal, meliputi pembelajaran inquiry secara aktif sampai dengan penyerapan pengetahuan dan fakta secara pasif, dengan memberdayakan 
pengetahuan dan pengalaman siswa untuk membantunya mengerti dan memahami dunia kehidupannya. (Kadir, $2014: 6$ ).

Pelaksanaan pembelajaran Tematik Terpadu berawal dari tema yang telah dipilih/dikembangkan oleh guru yang sesuai dengan kebutuhan peserta didik. Jika dibandingkan dengan pembelajaran konvensional pembelajaran tematik ini tampak lebih menekankan pada tema sebagai pemersatu berbagai mata pelajaran yang lebih diutamakan pada makna belajar, dan keterkaitan berbagai konsep mata pelajaran. Keterlibatan peserta didik dalam belajar lebih diprioritaskan dan pembelajaran yang bertujuan mengaktifkan peserta didik, memberikan pengalaman langsung serta tidak tampak adanya pemisahan antar mata pelajaran satu dengan lainnya (Kemendikbud, 2016: 12).

Selain itu, sebagai model pembelajaran di sekolah dasar/ madrasah ibtidaiyah, pembelajaran tematik memiliki karakteristik antara lain : berpusat pada siswa, memberikan pengalaman langsung, pemisahan mata pelajaran tidak begitu jelas, menyajikan konsep dari berbagai mata pelajaran, bersifat fleksibel, hasil pembelajaran sesuai dengan minta dan kebutuhan siswa serta menggunakan prinsip belajar sambil bermain dan menyenangkan.

Menurut Depdiknas (2006) dalam (Trianto, 2011: 162) pembelajaran tematik memiliki beberapa ciri khas antara lain : 1) Pengalaman dan kegiatan belajar sangat relevan dengan tingkat perkembangan dan kebutuhan anak usia sekolah dasar; 2) Kegiatan-kegiatan yang dipilih dalam pelaksanaan pembelajaran tematik bertolak dari minat dan kebutuhan siswa; 3) Kegiatan belajar akan lebih bermakna dan berkesan bagi siswa sehinggga hasil belajar dapat bertahan lebih lama; 4) Membantu mengembangkan keterampilan berpikir siswa; 5) Menyajikan kegiatan belajar yang bersifat pragmatis sesuai dengan permasalahan yang sering ditemui siswa dalam lingkungannya; dan 6) Mengembangkan keterampilan sosial siswa, seperti kerja sama, toleransi, komunikasi dan tanggap terhadap gagasan orang lain.

Dengan penelitian ini diharapkan akan mendapatkan hasil yang dapat menumbuh kembangkan budaya literasi terutama literasi baca-tulis pada pembelajaran tematik kelas tinggi dan upaya untuk mengatasi hambatan-hambatan dalam pelaksanaan gerakan literasi agar pelaksanaan gerakan literasi sekolah berjalan dengan maksimal.

\section{Metode}

Penelitian ini menggunakan jenis penelitian deskriptif kualitatif. Deskriptif adalah suatu penelitian yang diupayakan untuk mencandra atau mengamati permasalahan secara sistematis dan akurat mengenai faktadan sifat objek tertentu. Penelitian deskriptif ditujukan untuk memaparkan dan menggambarkan dan memetakan fakta-fakta berdasarkan cara pandang atau kerangka berpikir tertentu (Fathurrohman, 2017: 100).

Penelitian ini dilaksanakan di SD Negeri Kandang Panjang 10 Kota Pekalongan. Penelitian ini dilakukann di kelas IV dan V pada semester genap tahun ajaran 2018/2019. Teknik yang digunakan adalah menggunakan observasi, wawancara secara langsung dengan guru dan siswa kelas IV dan V SD N Kandang Panjang 10 Pekalongan, selanjutnya pengisian kuisioner angket yang dilakukan oleh siswa kelas IV dan V. Data selanjutnya peneliti meggunakan dokumentasi untuk memperkuat data penelitian. Dokumentasi yang didapatkan berupa daftar nama siswa kelas IV, V dan guru, jumlah siswa, tema yang digunakan saat pembelajaran di kelas, serta kondisi ruang kelas. Teknik analisis data menurut Miles dan Huberman (Sugiono, 2015: 246) Aktivitas dalam analisis data, yaitu : data reduction, data display, dan conclusion drawing/verification.

Mereduksi data berarti merangkum, memilih hal-hal pokok memfokuskan pada hal-hal penting, dicari tema dan polanya. Dengan demikian data yang telah direduksi akan memberikan gambaran yang lebih jelas, dan mempermudah peneliti untuk melakukan pengumpulan data selanjutnya, dan mencarinya bila diperlukan. Reduksi data dapat dibantu dengan peralatan elektronik seperti komputer mini, dengan memberikan kode pada aspek-aspek tertentu.

Setelah data di reduksi, maka langkah selanjutnya adalah mendisplaykan data. Dalam penelitian penyajian data dapat dilakukan dalam bentuk tabel, grafik, phi card, pictogram dan sejenisnya. Melalui penyajian data tersebut, maka data terorganisasikan, tersusun dalam pola hubungan, sehingga akan semakin mudah dipahami. Miles dan Huberman menyatakan yang paling sering digunakan untuk menyajikan data dalam penelitian kualitatif adalah dengan teks yang bersifat naratif. Dalam penelitian ini akan disajikan data gerakan literasi sekolah dan pembelajaran tematik menggunakan tabel serta uraian kata-kata untuk mendeskripsikan hasil penelitian.

Langkah ketiga dalam analisis data kualitatif menurut Miles dan Huberman adalah penarikan kesimpulan dan verifikasi. Kesimpulan awal yang dikemukakan masih bersifat sementara, dan akan berubah bila tidak ditemukan bukti-bukti yang kuat yang mendukung pada tahap pengumpulan data berikutnya. 
Kesimpulan dalam penelitian kualitatif merupakan temuan baru yang sebelumnya belum pernah ada. Temuan dapat berupa deskrepsi atau gambaran suatu obyek yang sebelumnya masih remang-remang atau gelap sehingga setelah diteliti menjadi jelas, dapat berupa hubungan kasual atau interaktif, hipotesis atau teori.

\section{Hasil dan Pembahasan}

Penelitian ini dilakukan pada tanggal 15 - 27 April 2019 di SD Negeri Kandang Panjang 10 Pekalongan. Berdasarkan hasil observasi danwawancara penelitian SD N Kandang Panjang 10 sudah melaksanakan gerakan literasi sekolah pada tahap pembiasaan dan tahap pembelajaran.

Tabel 1. Daftar Narasumber Penelitian

\begin{tabular}{|c|c|c|}
\hline Nama & Jabatan & Data yang Didapat \\
\hline Budi Herijanto, M.Pd & Guru Kelas IV A & Pendapat mengenai pelaksaan gerakan literasi \\
\hline Rohmah, S.Pd.SD & Guru Kelas IV B & sekolah pada pembelajaran tematik dan \\
\hline Mahmudah Rosaliana, S.Pd & Guru Kelas V A & kendalanya. \\
\hline Maryati, S.Pd & Guru Kelas V B & \\
\hline Dewi Maryanti & Siswa Kelas IV A & Tanggapan mengenai pelaksanaan gerakan \\
\hline Syakila Ni'matul Maula & Siswa Kelas IV A & literasi sekolah yang telah dilaksanakan didalam \\
\hline Mentari Anggun & Siswa Kelas IV A & kelas. \\
\hline Arif Setiawan & Siswa Kelas IV B & \\
\hline Riski Amalia & Siswa Kelas IV B & \\
\hline Rifa Miati & Siswa Kelas IV B & \\
\hline Safirna Dwi A & Siswa Kelas V A & \\
\hline Messya Yulistia & Siswa Kelas V A & \\
\hline Maheswari Laksita Sari & Siswa Kelas V A & \\
\hline M. Abi Khusna & Siswa Kelas VI B & \\
\hline Muhammad Rizki & Siswa Kelas VI B & \\
\hline Sekar Wulan Sari & Siswa Kelas VI B & \\
\hline
\end{tabular}

Hasil Observasi yang berkaitan dengan gerakan literasi SD Negeri Kandang Panjang 10 dapat diketahui jumlah fasilitator atau guru sudah memadahi, jumlah dan variasi bacaan yang terdapat di perpustakaan, serta terdapat kebijakan sekolah untuk meningkatkan gerakan literasi. Sekolah membuat jadwal kunjungan ke perpustakaan, setiap kelas memiliki kesempatkan 1 hari untuk mengenjungi perpustakaan pada jam tertentu, selain hari dan jam tersebut siswa tetap diperbolehkan mengunjungi perpustakaan pada saat istirahat. Dalam lingkungan sekolah dimana sepanjang koridor sebelah barat sekolahan sudah terdapat poster-poster yang dapat meningkatkan motivasi siswa untuk belajar. Sarana penunjang pelaksanaan gerakan literasi seperti mading juga terdapat di depan ruang guru, serta terdapat pojok buku disetiap ruang kelas. Dalam setiap kelas juga terdapat pohon literasi, akan tetapi kurang adanya bahan kaya teks untuk memperkaya pengetahuan siswa melalui membaca dari poster poster yang terdapat di dinding kelas.

Dalam pelaksaan gerakan literasi sekolah, guru selalu memanfaatkan fasilitas yang ada disekolahan untuk menunjang pelaksaan gerakan literasi seperti pemanfaat buku yang ada di perpustakaan dipinjam oleh guru dan diletakkan di pojok baca kelas untuk menambah daftar bacaan yang dapat dibaca siswa. Buku pengayaan yang dibaca siswa sesuai dengan jenjang kemampuan siswa dan sesuai dengan tema pembelajaran yang masih dipelajari. Strategi membaca yang digunakan guru (membacakan buku dengan nyaring, membaca terpandu, membaca bersama) untuk meningkatkan pemahaman peserta didik terhadap materi pembelajaran. Selama proses pembelajaran siswa memcatat materi pelajaran. Setiap kelas pasti terdapat buku pelajaran dan buku non-pelajaran. Rata-rata kelas buku yang terdapat di sudut baca sudah tertata dengan rapi sesuai dengan jenis bukunya.

Pada tahap pembiasaan guru membiasakan siswa untuk membaca 15 menit sebelum pembelajaran baik menggunakan metode membaca nyaring maupun membaca dalam hati. Pada tahap pembiasaan ini siswa dibebaskan dalam memilih buku yang akan dibaca, baik buku jenis fiksi maupun non fiksi yang sudah tersedia di pojok baca kelas. Guru tidak membatasi jumlah buku yang harus dibaca siswa tiap minggunya. Siswa diperbolehkan membaca buku sebanyak mereka mau. Pada tahapan pembelajaran, guru memanfaatkan buku pengayaan yang ada sesuai dengan tema dan subtema pembelajaran yang sedang berlangsung. 
Dalam pembelajaran tematik siswa membaca teks bacaan yang terdapat dalam buku pengayaan kemudian guru akan melontarkan pertanyaan yang terkait dengan bacaan dan siswa diminta untuk menjawabnya. Selain itu guru membentuk kelompok, satu kelompok terdiri dari dua orang dan meminta menuliskan hasil ada yang terlah mereka bahas selama pembelajaran tanpa membuka buka. Selesai dengan pekerjaan kelompoknya, maka tiap kelompok wajib mempresntasikannya ke depan kelas membacakan hasil diskusinya serta dibahas bersama-sama guna menyimpulkan pembelajaran hari tersbut.Selain itu guru juga membentuk kelompok, satu kelompok terdiri dari dua orang dan meminta menuliskan hasil ada yang terlah mereka bahas selama pembelajaran tanpa membuka buka. Selesai dengan pekerjaan kelompoknya, maka tiap kelompok wajib mempresntasikannya ke depan kelas membacakan hasil diskusinya serta dibahas bersama-sama guna menyimpulkan pembelajaran hari tersbut.

Dalam gerakan literasi yang dilaksanakan di SD N Kandang Panjang 10 sudah menerapkan dalam semua tahapan yaitu tahap pembiasaan, tahap pengembangan dan tahap pembelajaran. Literasi siswa kelas tinggi ini dapat dinyatakan baik dengan dibuktikan sebanyak 66 siswa dari jumlah keseluruhan 68 siswa menyatakan bahwa mereka suka membaca. Dalam angket tersebut juga menunjukkan sebagian besar siswa tidak merasa bosan apabila membaca buku yang berkaitan dengan materi pelajaran.

Pelaksanaan gerakan literasi sekolah siswa kelas tinggi dengan beberapa jenjang kemampuan literasi pada tahap pembelajaran rata-rata memperoleh lebih dari 50\% siswa kelas tinggi di SD N Kandang Panjang 10 mampu melaksanaan pada tiap jenjang kemampuan literasi. Pada jenjang kemampuan membaca siswa kelas tinggi dapat dikategorikan baik, karena pada tiap jenjang kemampuan membaca memperoleh skor rata-rata diatas 50\%. Pada jenjang kemampuan menulis juga dapat dikategorikan baik, karena sebagian besar memperoleh skor rata-rata diatas 50\%, hanya saja dalam kemampuan menulis siswa dengan menggunakan gaya bahasa sendiri siswa sendiri masuk dalam kategori kurang, karena hanya $39,70 \%$ siswa yang suka menulis dengan menggunakan gaya bahasa sendiri, selebihnya $60,29 \%$ menulis kembali menggunakan bahasa asli.

Dalam ranah kemampuan pemahaman tata bahasa $83,82 \%$ siswa bisa memahami dan membaca sesuai dengan intonasi tanda baca seperti titik, koma, tanda tanya, tanda seru dan tanda kutip. Kemampuan menggunakan konteks siswa dalam memahami arti kata/kalimat yang terdapat dalam bacaan mencapai angka $85,29 \%$ dan $83,82 \%$ siswa yang menyatakan jika terdapat kata/ kalimat yang belum dibapahami akan bertanya kepada guru. Ranah kemampuan yang menginterpretasi dan merespons bacaan, sebesar $75 \%$ siswa dapat menjawab semua pertanyaan yang terkait dengan bacaan dan $55,88 \%$ siswa menyatakan bahwa mereka tidak mengalami kesulitan dalam apabila diminta menjelaskan ulang informasi yang diperoleh dari membaca. Siswa yang menyatakan senang apabila diperintah oleh guru untuk membaca didepan kelas sebesar 70,58\% dengan jumlah satu buku yang dibaca setiap minggu siswa yang menyetujui pernyataan tersebut sebesar 58,82\%. Guru mencari metode pengajaran yang efektif dalam mengembangkan kemampuan literasi peserta didik 92,64\% siswa menyatakan bahwa guru kelas mereka selalu menggunakan cara yang menarik minat siswa untuk membaca. Guru melaksanakan pembelajaran dengan memaksimalkan pemanfaatan sarana dan prasarana literasi untuk memfasilitasi pembelajaran 72,05\% siswa menyatakan guru selalu meninta siswa menuliskan judul buku yang mereka baca di pohon literasi yang terdapat di dalam kelas. Dalam penerapan strategi membaca, sebesar 85,29\% menyatakan guru selalu menganjurkan membaca buku dengan nyaring, membaca terpandu, membaca bersama sebelum memulai pelajaran. Pernyataan bahwa siswa menulis materi pelajaran setiap hari 88,23\% siswa setuju dengan pernyataan tersebut.

Pada jenjang kemampuan menulis di SD pada tahap penulis awal, penulis bercerita melalui simbol gambar, huruf, kata, atau kalimat sederhana. Kosa kata tulis masih bercampur dengan kosa kata lisan. Pada penulis pemuda, penulis sudah berusaha memenuhi standar konvensi bahasa tulis, yaitu kosa kata, ejaan, dan tata bahasa. Penulis sudah dapat menulis kosa kata tulis, misalnya kata kerja dengan imbuhan dan tanda baca (titik, tanda seru, dan tanda tanya). Penulis juga dapat menulis kalimat utuh. Jenjang menulis di SD yang terakhir yaitu penulis madya, penulis dapat mengekspresikan ide melalui karangan dengan kosa kata tulis, menggabungkan narasi dan dialog dengan tanda baca yang benar dan kalimat yang bervariasi.

Kelompok jenjang kemampuan menulis di SD peserta didik dapat mengubah atau memodifikasi suatu cerita dan membuat ilustrasinya dalam kertas besar dengan pernyataan pada saat guru menyampaikan materi pelajaran siswa akan menulisnya dibuku memperoleh jawaban setuju sebesar 82,35\%, dengan pernyataan siswa dapat menuliskan kembali cerita karya orang lain kedalam bahasa siswa sendiri tanpa mengubah alur cerita memperoleh jawaban setuju sebesar 60,29\%, serta penyataan siswa suka mengisi waktu luang dengan menulis cerita fiksi (dongeng/novel) maupun non-fiksi (materi pelajaran/biografi tokoh) memperoleh jawaban setuju sebesar 75\%. Kemampuan menulis siswa dengan pernyataan siswa memperhatikan EYD dan tanda baca pada saat menulis memperoleh jawaban setuju 
sebesar $67,64 \%$, dan pernyataan sebelum menulis siswa menyusun pokok pikiran/kerangka karangan memperoleh jawaban setuju sebesar 77,94\%. Jenjang kemampuan menulis siswa bercerita melalui simbol gambar, huruf, kata, atau kalimat sederhana. Kosa kata tulis masih bercampur dengan kosa kata lisan dengan pernyataan siswa dapat mengekspresikan ide melalui karangan yang siswa tulis memperoleh jawaban setuju sebesar $76,47 \%$, sedangan pernyataan siswa menulis dengan kosa kata tulis, menggabungkan narasi dan dialog dengan tanda baca yang benar dan kalimat yang bervariasi memperolah jawaban setuju sebesar 85,29\%.

Menurut (Kemendikbud, 2016: 57) kegiatan literasi pada tahap pembelajaran meningkatkan kemampuan berbahasa reseptif (membaca dan menyimak) dan aktif (berbicara dan menulis). Dalam pelaksanaan gerakan literasi sekolah terdapat beberapa kendala yang dapat menghambat pelaksanaan gerakan literasi sekolah. Kendala dalam pelaksanaan gerakan literasi sekolah diantaranya yaitu kondisi lingkungan sekolah, faktor cuaca, waktu, serta sikap siswa dalam mengikuti pelaksanaan gerakan literasi.

Gerakan literasi dapat dikembangkan dalam kegiatan ekstraulikuler. Ekstrakulikuler yang ada di SD Negeri Kandang Panjang 10 seperti tari, pencak silat, dan musik. Pengemvbangan literasi dalam ekstrakulikuler yang ada di SD Negeri Kandang Panjang 10 Pekalongan contohnya musik yaitu solo song siswa diberi materi tentang pernafasan untuk dibaca lalu dipraktikan. Ketika pihak sekolah melibatkan publik dalam pelaksanaan gerakan literasi, maka ekosistem sekolah akan semakin terbuka dan sekolah mendapatkan kepercayaan yang semakin baik dari orang tua dan elemen masyarkat lain dalam mengembangkan literasi (Abidin, et al, 2017: 289-296).

Membaca pada dasarnya adalah mengkreasikan berbagai aktivitas agar siswa mampu mencapai tujuan yang diinginkan. Aktivitas yang dilakukan siswa sangat beragam, bergantung pada strategi membaca yang diterapkan dalam proses pembelajaran. Berdasarkan hal tersebut, pembelajaran membaca pemahaman merupakan serangkaian aktivitas yang dilakukan siswa, bukan sekedar membaca dan menulis. Jika sekedar membaca dan menulis, hal tersebut bukan proses pembelajaran, melaikan penilaian.

\section{Simpulan dan Saran}

Upaya-upaya menumbuhkan minat melalui gerakan literasi sekolah terlihat pada hasil pelaksanaan gerakan literasi sekolah pada tahap pembiasaan dan pengembangan sudah baik. Pelaksanan gerakan literasi juga dilakukan pada tahap pembelajaran yang dilaksanakan di setiap kelas pada saat pembelajaran dimulai. Gerakan literasi sekolah pada tahap pembelajaran telah diterapkan dalam pembelajaran tematik di kelas tinggi SD N kadang panjang 10 Pekalongan dengan optimal. Dengan adanya gerakan literasi sekolah pada pembelajaran tematik baik guru maupun siswa terbantu dalam proses pembelajaran. Terdapat beberapa hambatan pada saat pelaksanaan gerakan literasi sekolah diantaranya: kondisi lingkungan sekolah, faktor cuaca, waktu, serta sikap siswa dalam mengikuti pelaksanaan gerakan literasi. Upaya yang dilakukan untuk meminimalisir hambatan tersebut adalah melakukan kerja sama dengan orang tua siswa dengan cara guru memberi tugas yang berkaitan membaca/menulis yang dapat diselesaikan dirumah dengan bantuan orang tau/lingkungan sekitar.

Pelaksanaan gerakan literasi sekolah, guru sebaiknya menggunakan beragam cara/teknik agar siswa tidak mudah bosan ketika pelaksaan gerakan literasi sekolah. Pihak sekolah harus lebih memperhatikan sarana dan prasarana untuk fasilitas belajar siswa, serta ditunjang dengan kemampuan siswa untuk memperoleh infomasi secara mandiri melalui membaca.

\section{Daftar Rujukan}

Abidin, Y. et al. (2017). Pembelajaran Literasi Strategi Meningkatkan Kemampuan Literasi Matematika, Sains, Membaca, dan Menulis. Jakarta: Bumi Aksara.

Fathurrohman, M. (2017). Model-model Pembelajaran Inovatif. Jogjakarta: AR-RUZZ MEDIA.

Kadir, A. H. A. (2014). Pembelajaran Tematik. Depok: Rajawali Pers.

Kemendikbud. Peraturan Menteri Pendidikan dan Kebudayaan Republik Indonesia Nomor 23 Tahun 2016, 89 § (2016). Indonesia. https://doi.org/10.1016/j.athoracsur.2009.09.030

Sugiono. (2015). Metode Penelitian Pendidikan(Pendekatan Kuantitati, Kualitatif dan R\&D). Bandung: Alfabeta.

Trianto. (2011). Model Pembelajaran Terpadu: Konsep, Strategi, dan Implementasinya dalam Kurikulum Tingkat Satuan Pendidikan. Jakarta: Bumi Aksara. 